\title{
Strategi Pricing Policy Dalam Menarik Minat Wisatawan
}

\author{
${ }^{1}$ Kartika Dewi, ${ }^{2}$ Didin Syarifuddin, ${ }^{3}$ Sopa Martina \\ ${ }^{1}$ Sekolah Tinggi Pariwisata ARS Internasional, kartikadewi31294@gmail.com \\ ${ }^{2}$ Sekolah Tinggi Pariwisata ARS Internasional, didinars@yahoo.com \\ ${ }^{3}$ Sekolah Tinggi Pariwisata ARS Internasional, sopa.som@bsi.ac.id
}

\begin{abstract}
Abstrak
Taman Buah Mekarsari Bogor adalah salah satu pusat konservasi terbesar untuk keanekaragaman hayati buah-buahan tropis di dunia, terutama jenis buah-buahan unggul yang dikumpulkan dari semua daerah di Indonesia, serta tempat untuk penelitian budidaya (agronomi), pemuliaan dan perbanyakan benih unggul kemudian disebarluaskan kepada petani dan masyarakat umum. Penelitian ini adalah tipe deskriptif-verifikatif, sedangkan teknik pengambilan sampel yang digunakan adalah pengambilan sampel secara indindental dengan 100 responden. Teknik analisis data yang digunakan adalah analisis regresi linier berganda dengan uji hipotesis menggunakan uji koefisien determinasi analisis $\left(R^{\wedge}(2)\right)$, uji parsial (uji T). Penelitian ini dibantu dengan uji asumsi klasik yang terdiri dari uji normalitas dan uji autokerasi. Dari hasil uji statistik, diketahui bahwa kebijakan penetapan harga juga memiliki pengaruh positif dan signifikan terhadap minat wisatawan dengan koefisien kabupaten sebesar 0,793 , selain itu produk pariwisata dan pengaruh kebijakan harga terhadap minat wisata di Taman Buah Mekarsari sebesar 62,9\%.
\end{abstract}

Kata Kunci: Pricing Policy, Minat Wisatawan

\begin{abstract}
Mekarsari Fruit Park Bogor is one of the largest conservation centers for the biodiversity of tropical fruits in the world, especially the types of superior fruits collected from all regions in Indonesia, as well as a place for cultivation research (agronomy), breeding and propagation of superior seeds to then be disseminated to farmers and the general public.This research is descriptive-verifikative type, while the sampling technique used is incindental sampling with 100 respondents. The technique of data analysis used is multiple linear regression analysis with a hypothesis test using test of coefficient of determination analysis $\left(R^{2}\right)$, partial test (T test). This research was assisted with classical assumption test which consisting of normality test and autoceration test. From the statistical test result, it was known that pricing policy also had positive and significant influence to tourist interest with regency coefficient equal to 0.793 , besides tourism product and pricing policy influence to tourist interest in Taman Buah Mekarsari equal to 62,9\%.
\end{abstract}

Keywords: Pricing Policy, and Tourist Interest.

Diterima: 20 Agustus 2018, Direvisi: 15 Mei 2019, Diterbitkan: 15 Agustus 2019 


\section{PENDAHULUAN}

Bogor yang merupakan salah satu kota di Jawa Barat yang terletak di selatan Kota DKI Jakarta, dalam perkembangan perekonomiannya, masyarakat menitik beratkan pada bidang jasa dengan mengoptimalkan pemanfaatan sumber daya yang ada, terbukti dengan beragam destinasi wisata dan potensi lainya yang dimiliki Kota Bogor. Hal tersebut juga diperkuat dengan table data kunjungan wisata dibawah ini:

Tabel 1. Data Kunjungan Wisatawan Kota Bogor Tahun 2012-2016

\begin{tabular}{ccc}
\hline & Jumlah & Pertumbuhan \\
\cline { 3 - 3 } Tahun & Kunjungan & $(\%)$ \\
\hline 2012 & 361.551 & \\
\hline 2013 & 136.237 & $-62,30 \%$ \\
\hline 2014 & 215.306 & $58 \%$ \\
\hline 2015 & 263.932 & $22.6 \%$ \\
\hline 2016 & 230.407 & $-12,7 \%$ \\
\hline
\end{tabular}

Dapat disimpulkan Kota Bogor mengalami peningkatan kunjungan wisata setiap tahunnya walalupun tidak signifikan, ketidak signifikan tersebut diakibatkan persaingan destinasi wisata di seluruh kota di Indonesia dan salah satu faktor yang dapat mempengaruhi yaitu beragamnya daya tarik wisata yang dimiliki Kota Bogor yang akan menjadikan minat wisatawan untuk berkunjung ke Bogor.

Salah satu destinasi wisata di Kota Bogor dengan ciri khas wisata agronya adalah Taman Buah Mekarsari Bogor dengan berlokasi di Jl. Raya Cileungsi-Jonggol, Kec.Cileungsi, Kab.Bogor, Jawa Barat, menawarkan wisata rekreasi dan edukasi yaitu berwisata buah. Berikut ini adalah rekapitulasi pengunjung Taman Buah Mekarsari Bogor:

Tabel 2. Rekapitulasi Pengunjung Taman Buah Mekarsari Bogor Tahun 2012-2016

\begin{tabular}{cccc}
\hline \multirow{2}{*}{ Tahun } & \multicolumn{2}{c}{ Kunjungan Ke Destinasi } & \multirow{2}{*}{ Total } \\
\cline { 2 - 3 } & $\begin{array}{c}\text { Wisatawan } \\
\text { Nusantara }\end{array}$ & $\begin{array}{c}\text { Wisatawan } \\
\text { Mancanegara }\end{array}$ & \\
\hline 2012 & 1.775 .580 & 110.975 & 1.886 .555 \\
\hline 2013 & 3.227 .442 & 104.780 & 3.382 .222 \\
\hline 2014 & 4.148 .650 & 202.280 & 4.350 .930 \\
\hline 2015 & 4.561 .578 & 222.406 & 4.783 .848 \\
\hline 2016 & 5.017 .578 & 244.646 & 5.262 .233 \\
\hline
\end{tabular}

Dari hasil Tabel 2, menunjukan bahwa setiap tahunnya mengalami ketidakstabilan pertumbuhan yang mengakibatkan penurunan, hal tersebut menjadi suatu pokok permasalahan dalam penelitian ini, untuk mengatasi hal tersebut, penyedia jasa pariwisata haruslah memahami kebutuhan dan keinginan wisatawan yang mendasari serta membentuk preferensi seorang wisatawan dalam mengembangkan destinasi wisata.

Menurut Syarifuddin (2012) bahwa "Customer is a king. If the statement is related to a customer who always been to tourism destination, it become the tourist is a king pharpse is still relevant to current business conditiond, including tourism business". Wisatawan memiliki pengaruh yang besar dalam tingkat pemasukan sebuah destinasi wisata. Hal ini sejalan dengan pendapat Syarifuddin (2017) "Minat merupakan kesadaran seseorang yang dapat menimbulkan adanya keinginan. Keinginan yang timbul dalam diri individu tersebut dinyatakan dengan suka atau tidak suka, senang atau tidak senang terhadap sesuatu atau keinginan yang akan memuaskan kebutuhan".

Minat kunjungan mengalami penurunan bisa diakibatkan oleh berbagai faktor salah satunya adalah faktor lingkungan iternal/kegiatan internal perusahaan yang digunakan sebagai strategi pemasaran, kegiatan tersebut yaitu bauran pemasaran. Bauran pemasaran merupakan unsur pemasaran yang terdiri dari perencanaan produk, penetapan harga, program promosi, saluran distribusi. Berdasarkan hal tersebut maka faktor price sebagai unsur yang akan di teliti, karena harga merupakan satu-satunya unsur marketing mix yang menghasilkan pendapatan dan aspek penting dalam organisasi bisnis termaksud pada destinasi wisata.

Harga dapat menentukan seseorang membeli/tidak membeli produk, apalagi harga ini di pandang tidak sesuai oleh calon pembeli yang sangat sensitif terhadap perubahan harga .Oleh sebab itu, penulis mengambil variable Pricing Policy atau sering disebut kebijakan harga yang terdapat dalam faktor harga sebagai bahan penelitian dalam peneliti. Hal ini juga sejalan dengan pendapat Syarifuddin (2019) "Penetapan harga harus sesuai dengan kualitas produk yang ditawarkan agar wisatawan tertarik untuk membeli dan menggunakan produk wisata yang dijual dengan hal tersebut dapat meningkatkan minat berkunjung wisatawan".

Unsur harga tersebut dalam waktu tertentu dapat dirubah ataupun tidak. Apabila selama batas 
waktu tertentu keadaan menguntungkan, maka kebijakan harga itu masih digunakan, tetapi apabila situasi dan kondisi perusahaan mengalami perubahan, kebijakan harga tidak mungkin lagi untuk dipertahankan karena akan merugikan perusahaan maupun konsumen atau pengunjung.

Wisatawan mengenal istilah value for money di masa sekarang. Value for money adalah cara wisatawan membandingkan jumlah uang yang dibayarkan dengan kualitas fasilitas dan pelayanan yang diperolehnya. Berdasarkan penjelasan tersebut, maka penelitian ini bertujuan untuk mengetahui Kebijakan Harga di Taman Buah Mekarsari Bogor, dan pengaruhnya terhadap Minat Kunjungan Wisatawan di Taman Buah Mekarsari Bogor.

\section{KAJIAN PUSTAKA}

Harga merupakan unsur bauran pemasaran yang sifatnya fleksibel dimana setiap saat dapat berubah menurut waktu dan tempatnya. Menurut Fandy (2011:151) menyebutkan bahwa "harga merupakan satu-satunya unsur yang memberikan pemasukan atau pendapata bagi perusahaa".

Sedangkan Kotler (2016:324) mendefinisikan bahwa "Price the amount of money charged for a product or service, or the sum of the value that customers exchange for the benefits or having or using the product or service". Dimensi pricing policy menurut Koler (2012:52) adalah Kesesuain Harga (suitability price), Daftar Harga (price list), Potongan Harga (discounts), Harga yang dipersepsikan (price perception).

Minat menurut Djali (2013:121) adalah rasa lebih suka atau rasa ketertarikan pada suatu hal atau aktifitas, tanpa ada yang menyuruh, sedangkan Wisatawan menurut Kusumaningrum (2009:16), adalah orang yang sedang tidak berkerja, atau sedang berlibur dan secara sukarela mengunjungi daerah lain untuk mendapat sesuatu yang lain.

Dimensi Minat Wisatawan menurut Kotler, Philip (2009:179), menjelaskan mengenai teori AIDA yang terdiri dari Attention (Perhatian), Interest (Ketertarikan), Desire (Keinginan), Action (Tindakan).Keterkaitan harga dalam prilaku konsumen sangatlah berpengaruh dan akan di jelaskan berdasarkan model Gambar 1 .

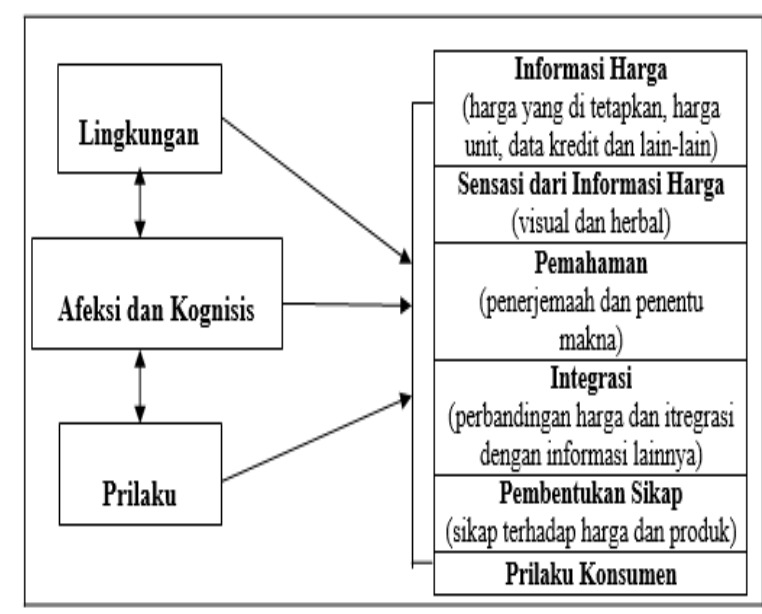

Gambar 1.

Model Konseptual Proses Kognitif dari Informasi Harga

Model ini menggabarkan suatu pendekatan untuk menjelaskan dampak harga untuk sebuah produk atau situasi pembelian yang tingkat keterlibatan tinggi. Pada dasarnya model tersebut menyatakan bahwa informasi harga diterima melalui indra penglihatan dan pendengaran. Informasi tersebut kemudian dipahami secara keseluruhan, yaitu informasi tersebut diterjemahkan dan dibuat bermakna, misalnya konsumen memahami makna dari simbol harga melalui apa yang dipelajari dan dialami sebelumnyam(Sunyoto, 2013:180). Berdasarkan penjelasan tersebut dapat disimpulkan bahwa harga yang ditawarkan kepada wisatawan akan berpengaruh terhadap keinginan/minat wisatawan dalam berkunjung ke destinasi wisata.

\section{METODE PENELITIAN}

Metode penelitian yang digunakan dalam penelitian ini adalah metode deskriptif verifikatif. Penelitian deskriptif - verifikatif adalah penelitian yang menjelaskan masalah dalam variabel yang diteliti serta menjelaskan hubungan yang bersifat kausalitas dari variable pengaruh terhadap variable terpengaruh (Sugiyono, 2014:111) dan lokasi penelitian yang dipilih adalah Taman Buah Mekarsari Bogor.

Variabel pada penelitian ini adalah Pricing Policy dan Minat Wisatawan. Melalui penelitian deskriptif ini maka diperoleh hasil deskriptif tentang tanggapan responden mengenai Strategi Pricing Policy, dan Minat Kunjungan Wisatawan Taman Buah Mekarsari Bogor. Sedangkan Melalui penelitian verifikatif ini maka penulis bertujuan untuk mengetahui pengaruh Pricing Policy dan Minat Kunjungan Wisatawan Taman Buah Mekarsari Bogor. 
Berdasarkan jenis penelitiannya, yakni deskriptif verifikatif yang dilaksanakan melalui pengumpulan data lapangan, maka metode penelitian yang akan digunakan adalah metode explanatory survey. Survey informasi didapat dari sebagian populasi (sample respondent) dan dikumpulkan langsung di tempat kejadian, dengan tujuan untuk mengetahui pendapat dari sebagian populasi terhadap objek yang diteliti.

Populasi pada penelitin ini adalah wisatawan Taman Buah Mekarsari Bogor. Berkaitan dengan populasi tersebut maka penelitian ini mengambil dari jumlah wisatawan pada saat kuesioner akan di bagikan yaitu pada saat weekday dan weekend yaitu hari jumat dan sabtu. Teknik pengambilan sampel yang digunakan adalah Accidental Sampling. Pengumpulan data dilakukan dengan menyebarkan kuesioner kepada wisatawan Taman Buah Mekarsari Bogor. Jumlah sampel sebanyak 100 responden wisatawan Taman Buah mekarsari Bogor.

\section{Instrumen Penelitian}

Instrumen penelitian digunakan untuk melakukan pengukuran dengan tujuan menghasilkan data kuantitatif yang akurat, efisien dan komunikatif, maka setiap instrumen harus memiliki skala. Berdasarkan variabel-variabel penelitian yang digunakan dan pemaparan sebelumnya yang menyatakan bahwa penelitian ini menggunakan kuesioner atau angket sebagai instrumen utama, maka dapat diketahui skala yang digunakan dalam penelitian ini adalah skala likert. Setiap ukuran yang menggunakan skala ini mempunyai tingkatan dari sangat positif sampai sangat negatif, yang dapat diberi skor sebagai berikut:

Tabel 3. Rentang Skor Nilai alternatif

\begin{tabular}{clc}
\hline No & \multicolumn{1}{c}{ Jawaban } & Skor \\
\hline 1 & Sangat Setuju & 5 \\
\hline 2 & Setuju & 4 \\
\hline 3 & Cukup & 3 \\
\hline 4 & Tidak Setuju & 2 \\
\hline 5 & Sangat Tidak Setuju & 1
\end{tabular}

Sumber: Sugiyono (2015)

\section{Teknik Pengumpulan Data}

Teknik pengambilan data yang di gunakan dalam penelitian ini adalah penelitian lapangan yang terdiri dari:
a. Wawancara (Interview)
b. Observasi
c. Kuesioner
d. Studi Kepustakaan

\section{Teknik Pengujian Data}

Suatu hasil penelitian dikatakan valid jika terdapat kesamaan diantara data yang terkumpul dengan data yang sesungguhnya terjadi, sedangkan hasil penelitian dikatakan realiabel jika terdapat kesamaan data dalam waktu yang berbeda.

\section{Validitas dan Reliabilitas}

Pengujian validitas dalam penelitian ini menggunakan korelasi rank spearman. Hasil uji validitas menunjukkan semua nilai $r$ hitung menunjukkan hasil perhitungan di atas $0.361(r$ table). Hasil tersebut memberikan gambaran bahwa semua kuesioner yang digunakan dalam uji validitas tersebut, dapat dilanjutkan untuk pengambilan data berikutnya. Pengujian reliabilitas dalam penelitian ini dilakukan dengan menggunakan koefisien Cronbach Alpha. Hasil uji reliabilitas menunjukkan semua nilai $r$ hitung menunjukkan hasil perhitungan di atas $0.60(r$ table) maka semua variabel dalam penelitian ini sudah reliable.

\section{HASIL DAN PEMBAHASAN}

\section{Hasil Penelitian}

Hasil analisis daya deskriptif dari penelitian ini menunjukan bahwa dari 100 responden yang berjenis kelamin perempuan sebanyak $61 \%$ dan laki-laki sebanyak 39\% dengan responden usia pengunjung paling banyak yaitu usia produktif (25-56 Tahun) sebesar 52\% yang berdomisili di Bogor sebesar $48 \%$.

Pendidikan terakhir responden kebanyakan SMU/SMK sebesar $41 \%$ dan pekerjaan sebagian besar pegawai swasta dengan pendapatan responden paling banyak berkisar Rp 2.000.000Rp4.000.000. Hasil penelitian ini juga menunjukan sebagian besar alasan utama responden mengunjungi dikarenakan tempat mudah dijangkau dan responden cukup sering (25 kali) berkunjung sebanyak $44 \%$.

\section{Analisis Deskriptif Variabel Pricing Policy (X)} Pada variabel kebijakan harga dengan jumlah pertanyaan sebanyak 8 item dan jumlah responden sebanyak 100 responden, diperoleh skor total sebesar 2.899 dengan presentase $72,5 \%$. Maka, interval skor setiap kategori ditentukan dengan menggunakan rumus Sugiyono (2013:80). 


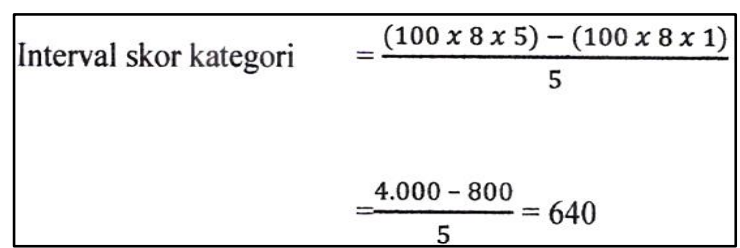

Gambar 2.

Interval Skor Katagori Pricing Policy

Jadi, panjang interval untuk setiap kategori adalah 640. Dari interval yang sudah dihitung tersebut, dapat diketahui kategorisasi variabel kebijakan harga sebagai berikut:

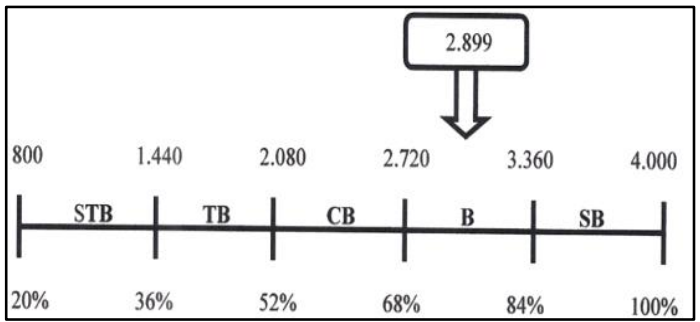

Gambar 3.

Panjang Interval Skor Katagori Pricing Policy

Berdasarkan interval skor di atas, skor total variabel kebijakan harga sebesar 2.899 berada pada interval 2.720-3.360 dan termasuk ke dalam kategori "Baik". Artinya, kebijakan harga di Taman Buah Mekarsari sudah baik dimata responden dan sesuai dengan wisatawan.

Analisis Deskriptif Variabel Minat Wisatawan Pada variabel minat wisatawan dengan jumlah pertanyaan sebanyak 8 tem dan jumlah responden sebanyak 100 responden, diperoleh skor total sebesar 3.107 dengan presentase 77,7\%. Maka, interval skor setiap kategori ditentukan dengan menggunakan rumus Sugiyono (2013:80), sebagai berikut:

$\begin{aligned} \text { Interval skor kategori } & =\frac{(100 \times 8 \times 5)-(100 \times 8 \times 1)}{5} \\ & =\frac{4.000-800}{5}=640\end{aligned}$

Gambar 4.

Interval Skor Katagori Pricing Policy

Jadi, panjang interval untuk setiap kategori adalah 640. Dari interval yang sudah dihitung tersebut, dapat diketahui kategorisasi variabel minat wisatawan sebagai berikut:

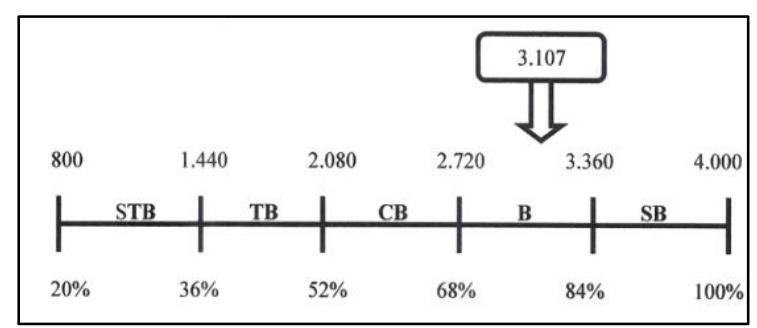

Gambar 5.

Panjang Interval Skor Katagori Pricing Policy

Berdasarkan interval skor di atas, skor total variabel minat wisatawan sebesar 3.107 berada pada interval 2.720-3.360 dan termasuk ke dalam kategori "Baik".

\section{Uji Normalitas}

Normalitas dalam penelitian ini dapat diketahui dengan membandingkan nilai Asymp Sig. dengan nilai signifikansi $\alpha(0,05)$ pada hasil perhitungan statistik oleh software SPSS 16 for Windows. Hasil uji normalitas menunjukan bahwa nilai Asymp Sig. dari masing-masing variable > (lebih dari) signifikansi $\alpha(0,05)$. Dengan demikian, dapat disimpulkan bahwa data berdistribusi normal.

\section{Uji Autokolerasi}

Tabel 4. Hasil Uji Autokolerasi

Model Summary ${ }^{b}$

\begin{tabular}{llccrr}
$\begin{array}{l}\text { Mo } \\
\text { del }\end{array}$ & R & R Square & $\begin{array}{c}\text { Adjusted R } \\
\text { Square }\end{array}$ & $\begin{array}{c}\text { Std. Error of } \\
\text { the Estimate }\end{array}$ & $\begin{array}{c}\text { Durbin- } \\
\text { Watson }\end{array}$ \\
\hline 1 & $.793^{\text {a }}$ & .629 & .625 & 2.25314 & 1.692 \\
\hline a. Predictors: (Constant), Kebijakan Harga \\
\multicolumn{7}{l}{ b. Dependent Variable: Minat Wisatawan } \\
\hline
\end{tabular}

Autokorelasi dalam penelitian ini dapat diketahui dengan melihat nilai DW (Durbin-Watson) pada hasil perhitungan statistik oleh software SPSS 16 for Windows. Hasil uji autokorelasi menunjukan bahwa nilai Durbin Watson $=1,692<2$. Dengan demikian, dapat disimpulkan bahwa tidak terdapat autokorelasi pada model ini. 
Analisis Koefisien Regresi Linear Sederhana

Tabel 5. Analisis Koefisien Regresi Linear Sederhana

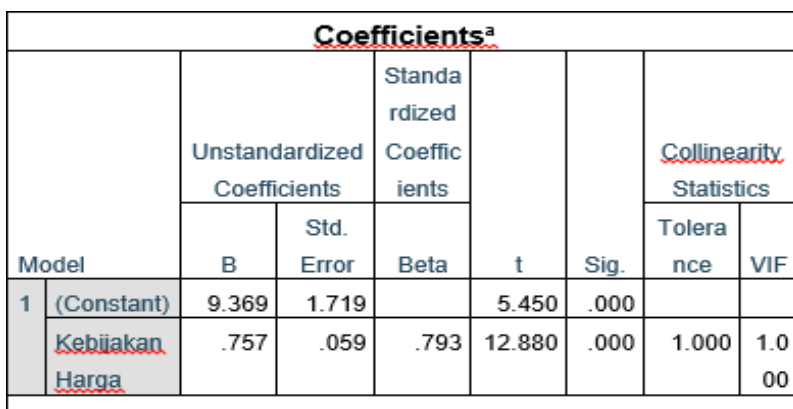

a. Dependent Variable: Minat Wisatawan

Koefisien Regresi Linear Sederhana untuk $x$ sebesar 0,793 dan bertanda positif dengan signifikansi 0,000 . Hal ini berarti bahwa setiap peningkatan minat wisatawan akan memberikan peningkatan skor sebesar 0,793 .

\section{Analisis Koefisien Determinasi $\left(\mathbf{R}^{2}\right)$}

Koefisien determinasi pada penelitian ini dapat diketahui dengan melihat nilai $R$ square pada hasil perhitungan statistik untuk mengetahui pengaruh variabel independen terhadap variabel dependen yang dilakukan menggunakan software SPSS 16 for Windows seperti yang ditunjukan pada tabel dibawah ini:

Tabel 6. Hasil Uji Koefesien Determinasi $\left(\mathrm{R}^{2}\right)$

\begin{tabular}{|c|c|c|c|c|c|}
\hline \multicolumn{6}{|c|}{ Model Summary ${ }^{\mathrm{b}}$} \\
\hline $\begin{array}{l}\text { Mo } \\
\text { del }\end{array}$ & $\mathrm{R}$ & R Square & $\begin{array}{l}\text { Adjusted R } \\
\text { Square }\end{array}$ & $\begin{array}{l}\text { Std. Error of } \\
\text { the Estimate }\end{array}$ & $\begin{array}{l}\text { Durbin- } \\
\text { Watson }\end{array}$ \\
\hline 1 & $.793^{\mathrm{a}}$ & .629 & .625 & 2.25314 & 1.692 \\
\hline \multicolumn{6}{|c|}{ a. Predictors: (Constant), Kebijakan Harga } \\
\hline & ( & 1 & Finat Wisatav & & \\
\hline
\end{tabular}

Hasil uji koefisien determinasi $\left(\mathrm{R}^{2}\right)$. Dari Tabel 6 diatas, dapat dilihat bahwa nilai $\mathrm{R}$ square $=$ 0,629 . Hal ini mengindikasikan bahwa Pricing Policy berpengaruh terhadap minat wisatawan di Taman Buah Mekarsari Bogor, sebesar 62,9\%, sedangkan sisanya, yaitu 37,1\% dipengaruhi oleh variabel-variabel lain yang tidak diteliti dalam penelitian ini.

\section{Uji Parsial (Uji T)}

Uji parsial pada penelitian ini dapat diketahui dengan melihat nilai ( $\mathrm{T}$ ) pada hasil perhitungan statistik oleh software SPSS 16for Windows, seperti yang ditunjukan pada tabel berikut ini:
Tabel 7. Hasil Uji Parsial (Uji T)

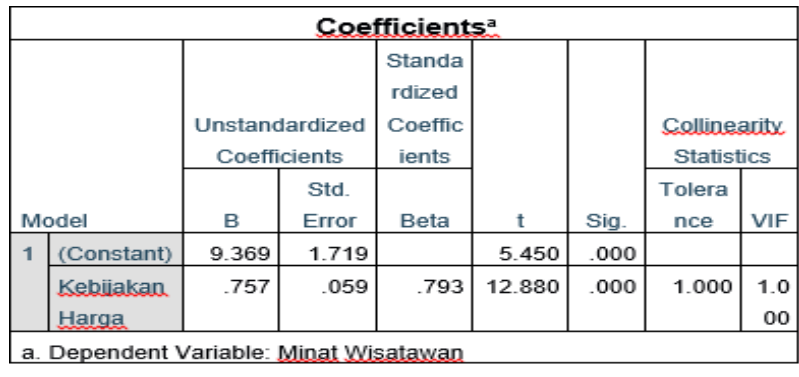

Hasil uji $\mathrm{T}$ berupa pengaruh variabel $\mathrm{X}$ (Pricing Policy) terhadap Y (minat wisatawan), sebagai berikut, bahwa terdapat pengaruh pricing policy terhadap minat wisatawan secara parsial. Dari Tabel 7 tersebut, dapat dilihat bahwa nilai $\mathrm{t}$ hitung $=12,880$ dan signifikansi hitung $=0,000$. Dengan menggunakan batas signifikansi $\alpha(0,05)$ dan derajat kebebasan (df) n-k-1 atau 100-2-1 = $97(\mathrm{n}=$ jumlah respondendan $\mathrm{k}=$ jumlah variabel independen), diperoleh $\mathrm{t}$ tabel sebesar 1,66071. Artinya, $\mathrm{t}$ hitung $>\mathrm{t}$ tabel dan signifikansi hitung <.a. Dengan demikian, $\mathrm{H}_{0}$ ditolak dan $\mathrm{H}_{\mathrm{a}}$ diterima dengan keterangan sebagai berikut:

1) $\mathrm{H}_{0}: \rho \mathrm{yx}_{2}=0$ Pricing Policy tidak berpengaruh signifikan terhadap minat wisatawan secara parsial.

2) $\mathrm{H}_{\mathrm{a}}: \rho \mathrm{yx}_{2} \quad \neq 0 \quad$ Pricing Policy berpengaruh signifikan terhadap minat wisatawan secara parsial.

\section{Temuan Penelitian}

Pemilihan tempat rekreasi yang cendrung ke alam yang jauh dari polusi dan kebisingan, menjadikan wisata alam sebagai pilihan wisatawan untuk berlibur. Hal ini pun yang menimbulkan persaingan wisata khususnya di Kota Bogor dalam mengembangkan objek wisata masing-masing. Salah satu obyek wisata di Kota Bogor dengan ciri khas wisata agronya yaitu Taman Buah Mekarsari, yang merupakan salah satu pusat pelestarian keanekaragaman hayati buah-buahan tropika, khususnya buah-buah unggulan yang dikumpulkan dari seluruh daerah di indonesia.

Perkembangan objek wisata agro sejenis Taman Buah Mekarsari sekarang sudah banyak, oleh sebab itu perusahaan harus mampu menarik minat wisatawan untuk berkunjung dengan mengetahui apa yang diinginkan dan dibutuhkan oleh wisatawan supaya tertarik dan berminat untuk berwisata. Pada penelitian ini pada dasarnya adalah untuk mengetahui Strategi Pricing Policy terhadap minat wisatawan di Taman Buah Mekarsari Bogor. 
Hasil analisis terhadap Pricing Policy yang ditetapkan oleh Taman Buah Mekarsari Bogor dinyatakan penting karena wisatawan menginginkan harga yang sesuai dengan harapannya. Kesesuain tersebut diharapkan dari harga produk di Taman Buah Mekarsari Bogor sudah sesuai dengan harapan dan keinginan wisatawan.

Hal ini juga sudah diperkirakan oleh perusahaan bahwa wisatawan akan mempertimbangkan harga sebelum membeli produk yang di dukung oleh (Tjiptono, 2008:154) mengenai faktor yang mempengaruhi penetapan harga yaitu "persepsi konsumen terhadap harga dan nilai, ketika menetapkan harga perusahaan harus mempertimbangkan persepsi harga konsumen dan bagaimana persepsi ini mempengaruhi keputusan pembelian konsumen dan harga dan pesaing, jika suatu perusahaan mengetahui harga dan penawaran pesaing, perusahaan tersebut dapat menggunakannya sebagai penimbangan dalam penetapan harganya sendiri.

Jika penawaran perusahaan sama dengan pesaing utamanya, perusahaan harus menetapkan harga terdekat dengan harga pesaing atau ia akan kehilangan order penjualannya”. Hasil tanggapan responden terhadap minat wisatawan ke Taman Buah Mekarsari Bogor, mendapatkan respon tinggi yang positif dan signifikan. Pada dasarnya sebelum berkunjung dan membeli suatu produk wisata, wisatawan melalui tahap awal yaitu perhatian (Attention) dimana produk wisata tersebut telah menarik perhatian calon wisatawan dan timbul ketertarikan (Interest) dimana seseorang memiliki perasaan ingin tahu lebih dalam tentang sesuatu hal yang jadi daya tarik sehingga muncul kemauan (Desire) yang muncul dari hati tentang sesuatu yang menarik perhatian dan melakukan sesuatu hal yaitu dengan sebuah tindakan (Action) dimana wisatawan pada akhirnya memutuskan untuk berkunjung ke objek wisata Taman Buah Mekarsari Bogor.

Secara umum prilaku konsumen dapat ditunjukan bahwa dalam melakukan pembelian konsumen akan memilih jenis produk wisata yang ditawarkan, harga yang sesuai dengan fungsi produk dan manfaat yang baik sesuai dengan harga yang ditawarkan dan wisatawan pada akhirnya mendapatkan kepuasan.

Hal ini didukung dengan teori Djaali (2013) menyatakan bahwa "minat adalah rasa lebih suka atau rasa ketertarikan pada suatu hal atau aktifitas, tanpa ada yang menyuruh". Berdasarkan hal tersebut maka dapat di ambil kesimpulan bahwa Pricing Policy memiliki keterkaitan/hubungan dalam menarik minat wisatawan karena faktor harga merupakan salah satu hal yang dipertimbangkan wisatwan dalam berkunjung.

\section{SIMPULAN DAN REKOMENDASI}

Dari hasil penelitian tentang Pricing Policy terhadap minat kunjungan wisatawan Taman Buah Mekarsari Bogor ini, maka dapat diambil kesimpulan bahwa pricing Policy di Taman Buah Mekarsari Bogor tercapai dengan skor total 2.899 (skor ideal 4.000) dan dengan tingkat persentase sebesar $72.5 \%$. Berdasarkan interval skor, skor total variabel Pricing Policy sebesar 2.899 berada pada interval 2.720-3.360 dan termasuk kedalam kategori "Baik". Artinya, kebijakan harga di Taman Buah Mekarsari Bogor ditanggapi "Baik" oleh responden. Minat Wisatawan di Taman Buah Mekarsari Bogor tercapai dengan skor total 3.170 (skor ideal 4.000) dan dengan tingkat persentase sebesar $77,7 \%$. Berdasarkan interval skor, skor total minat wisatwan sebesar 3.170 berada pada interval 2.720-3.360 dan termasuk kedalam kategori "Baik". Artinya, minat wisatwan di Taman Buah Mekarsari Bogor ditanggapi "Baik" oleh responden. Berdasarkan hasil hitung regresi linier sederhana diperoleh bahwa variabel Pricing Policy (X) memiliki koefisien regresi sebesar 0,793 (bertanda positif) terhadap minat wisatawan (Y). Dan untuk hasil pengujian uji parsial (uji $\mathrm{T}$ ) diperoleh nilai $\mathrm{t}$ Hitung > t Table yaitu sebesar 12,880 > 1.6671 dengan tingkat signifikan 0,000 . Hal ini berarti bahwa Pricing Policy (X) berpengaruh positif terhadap minat wisatawan. Sesuai dengan hipotesis yang menyatakan bahwa terdapat pengaruh Pricing Policy atau kebijakan harga terhadap minat wisatawan di Taman Buah Mekarsari Bogor. Maka hipotesis $\mathrm{H}_{2}$ diterima. Berdasarkan hasil hitung uji koefisien determinasi $\left(\mathrm{R}^{2}\right)$ diperoleh bahwa koefisien determinasi $\left(\mathrm{R}^{2}\right)$ yang diperoleh sebesar 0,629 hal ini berarti $62,9 \%$ minat wisatawan dapat dipengaruhi oleh produk wisata dan kebijakan harga dan sisanya $37,1 \%$ dipengaruhi oleh variabel-variabel lain yang tidak di jelaskan dalam model regresi ini.

Berdasarkan kesimpulan yang diperoleh maka, saran-saran yang dapat diberikan untuk Taman Buah Mekarsari Bogor adalah sebagai berikut bahwa indikator Pricing Policy atau Kebijakan Harga yang memiliki skor terendah adalah potongan harga. Dalam hal ini Taman Buah Mekarsari Bogor disarankan supaya dapat lebih sering memberikan potongan harga pada hari-hari 
besar terutama ulang tahun Taman Buah Mekarsari Bogor supaya wisatawan tertarik dan berminat untuk berwisata.

Indikator Minat Wisatawan yang memiliki skor terendah adalah tentang koleksi buah-buahan yang di miliki Taman Buah Mekarsari Bogor. Dalam hal ini Taman Buah Mekarsari Bogor disarankan untuk lebihmengembangkan dan menambah koleksi buah-buahan lokal maupun mancanegara, selain itu juga buah-buah langka dari berbagai negara, supaya wisatawan lebih berminat berwisata. Pricing Policy yang ditawarkan Taman Buah Mekarsari Bogor sudah sesuai dengan apa yang diharapkan oleh wisatawan, namun masih ada sebagian kecil wisatawan yang tidak sesuai dengan harga yang ditawarkan. Apabila nanti harga akan dinaikan maka harus disertai dengan peningkatan produk wisata tersebut, supaya lebih mencangkup kesemua kalangan, dan penambahan produk dalam segi wahana. Walaupun segmentasi Taman Buah Mekarsari Bogor adalah kalangan menengah ke atas, tidak dipungkiri di kalangan menengah kebawah pun daya minatnya cukup tinggi, oleh sebab itu produk di sesuaikan dengan harga yang dapat terjangkau oleh semua kalangan dan juga memberikan potongan harga pada saat event tertentu yang akan meningkatkan minat wisatawan.

Penelitian selanjutnya disarankan untuk menambah variabel independen lainnya selain Pricing Policy atau kebijakan harga yaitu tentunya dapat mempengaruhi variabel dependen yaitu minat wisatawan agar lebih melengkapi penelitian ini. Karena masih ada variabel-variabel independen lain di luar penelitian ini yang mungkin mempengaruhi minat wisatawan.

\section{DAFTAR PUSTAKA}

Djaali. (2013). Pisikologi Pendidikan (7th ed.). Jakarta: Bumi Aksara.

Djali. (2013). Pisikologi Pendidikan (7th ed.). Jakarta: Bumi Aksara.

Fandy, T. (2011). Pemasaran Jasa. Bayumedia. Malang: Bayumedia.

Koler, P., and A. (2012). Principles of Marketing (14th ed.). New Jersey: Prentice Hall.

Kotler, Philip, dan K. L. K. (2009). Manajemen Pemasaran (13th ed.). Jaka: Erlangga.

Kotler, P. and G. A. (2016). Prinsip-prinsip Pemasaran. Jakarta: Erlangga.

Kusumaningrum, D. (2009). Persepsi Pengunjung Nusantara Terhadap Daya TarikWisata Di Kota Palembang. Universitas Gadjah Mada.

Sugiyono. (2014). Metode Penelitian Kombinasi (Mix Methode). Bandung: Alfabeta.

Sunyoto, D. (2013). Dasar-Dasar Manajemen Pemasaran. Yogyakarta: CAPS.

Syarifuddin, D. (2012). Increasing Number Of Tourist By Means of Building Tourist Value. 1.

Syarifuddin, D. (2017). Dampak Lingkungan Terhadap Minat Mahasiswa Pariwisata Berwirausaha, 4, 44.

Syarifuddin, D. (2019). Strategi Penetapan Harga Dalam Meningkatkan Minat Berkunjung Wisatawan Di Villa Kancil Kampoeng Soenda Majalaya, 2, 232.

Tjiptono, F. (2008). Strategi Pemasaran. Yogyakarta: ANDI. 